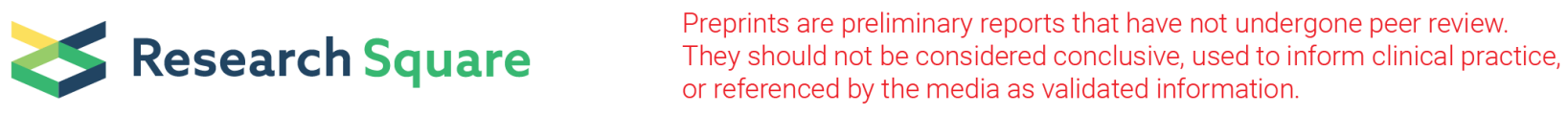

\title{
The Role of Social Capital on Utilization of Maternal and Child Health Services in Low- and Middle- Income Countries: Mixed-Methods Review
}

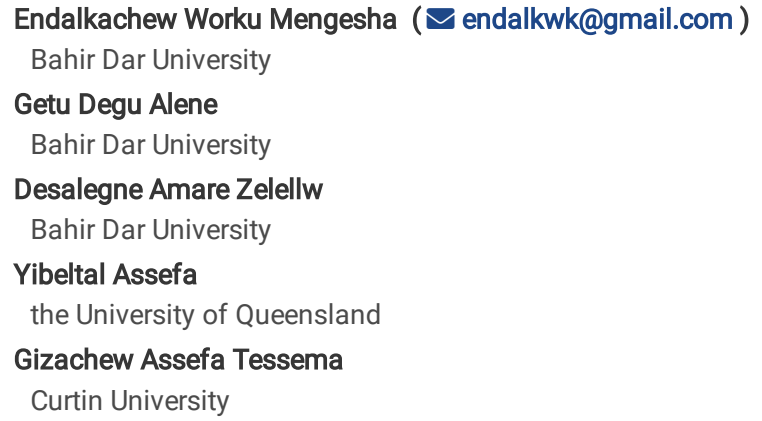




\section{Abstract}

Background: Social capital is defined as social relations that may provide individuals and groups with access to resources and supports in community networks. It has become an important issue to be studied in the field of public health. This study aimed to review pieces of literature about the role of social capital on the utilization of maternal and child health services in low- and middle- income countries.

Methods: Mixed-methods research review and synthesis, using three databases (PubMed, Scopus, and Science Direct), was performed. Besides, Google Scholar and Google search engines were used. Both quantitative and qualitative studies conducted in low- and middle- income countries, published in English, in grey and commercial literature were considered.

Results: A total of 1,545 studies were identified, of which, 328 records were removed due to duplication. Then, 13 records were selected after reading titles, abstracts, and full texts. Of these eligible studies, six studies were included for quantitative synthesis, and seven of them for qualitative synthesis. Moreover, six quantitative studies and seven qualitative studies were included. Of the six reviewed quantitative studies, five of them addressed the relationship between social capital and health facility delivery. Likewise, women who lived in communities with higher membership in groups that help form intergroup bridging ties had higher odds of antenatal care use. Synthesized qualitative findings revealed that women received some form of emotional, informational, and instrumental support from their network members. Receiving health information from trusted people and socio-cultural factors influenced the use of maternal health services.

Conclusions: Social capital has a great contribution to the utilization of maternal and child health services. Countries aiming to reduce maternal mortality should identify context-specific approaches to benefit from its social capital. On the other hand, measurement tools for social capital require due attention as there is no uniformity across studies and most of them were conducted using a cross-sectional design. Hence, further longitudinal and interventional studies should be employed to pin down the direction of causality.

\section{Systematic review registration: PROSPERO CRD42021226923}

\section{Background}

Maternal and child mortality is declining in the last two decades but remains relatively high in the low- and middle- income countries (LMICs). About $86 \%$ of global maternal deaths occurred in two regions, sub-Saharan Africa (SSA) alone accounted for $66 \%$, and nearly $20 \%$ in southern Asia [1-3]. Although global neonatal mortality rate was decreased by $51 \%$, from 36 deaths per 1000 live births in 1990 to 18 deaths per 1000 live births in 2017 , still, 2.5 million children died in the first month of life [4]. Sustainable Developmental Goals (SDGs) have target of less than 70 maternal deaths per 100000 live births and to reduce to about 1.2 million neonatal deaths by 2030. The ambition of these SDGs targets can be achieved by improving maternal and child health services uptake, especially in the high-burden regions of south Asia and SSA [4].

Use of maternal and child health services $(\mathrm{MCH})$ are essential for the early detection of mothers and infants at high risk of morbidity and mortality. Although there have been improvements in $\mathrm{MCH}$ services coverage, overall $\mathrm{MCH}$ indicators remained low with disparities between the lowest and highest wealth quintiles $[5,6]$. The studies in developing countries stated that high maternal and child mortality was highly related to low level of antenatal care (ANC) visits, facility based delivery, immunization, decision making capacity of women and social capital scores [7-14]. Social capital (SC) can play a role in improving health services uptake and it has been positively related to physical and mental health of members in the social networks $[15,16]$.

Social capital has multiple definitions and concepts in the field of economics, sociology, political science, public health and other disciplines [17]. Recently, it has become an important issue in field of public health [18]. Social capital is defined as social relations that may provide individuals and groups with access to resources and supports in their community networks. It may include different forms such as exchange of favors, maintenance of group norms, trust towards individuals or groups, and supports offered to members of social groups [19]. A number of social capital theories were grounded so far and growing from individual and family property to features of communities and nations [20-22]. The theory of SC can be explained in structural and cognitive forms. In the structural form, it focuses on the externally observable aspects of social organizations and refers to the intensity of an individual's participation in community networks measured in objective terms [23]. The cognitive form involves subjective aspects such as norms, values, attitudes and perceptions of an individual's social relationship and can be measured subjectively. Structural and cognitive forms of SC are not mutually exclusive and characterized in terms of social relations as what people 'do' and what people 'feel', respectively [15, 24, 25].

Some public health researchers focused on the distinction of social capital into 'bonding', 'bridging', and 'linking' which are highly related to structural SC [24, 26 , 27]. Bonding capital comprises relations within homogeneous groups, in terms of establishing strong intra-group ties that connect family members, neighbors, and close friends. Bridging capita/ refers to weak ties between individuals or groups that possess little social participation. For example, people from different ethnic and occupational backgrounds may attain relatively weak social connections. Linking capital exists among those individuals and groups involved in hierarchical or unequal relations due to differences in power, status, and resources [24, 28].

A study conducted in five LMICs showed that neighborhood social capital has better contribution in LMICs than high-income countries, potentially due to differences in neighborhood environments, health systems, and availability of public resources. In addition, China had the highest level of trust in neighbors; South Africa and Ghana had very high level of community participation and Ghana showed the highest score of perceived safety in the residential neighborhood [29]. Likewise, women in Ethiopia had high levels of group membership, high participation in citizenship activities and high levels of cognitive social capital[30]. Women who involved in social networks including 'Debo' and 'Equb' could access information. These networks also provide economic and social support to the members and beyond [31]. Social capital influences use of maternal and child health services through social networks between communities or community members and representatives of formal institutions such as health care providers, teachers and government officers [32]. 
Moreover, involvement of religious leaders, health extension workers, women developmental army leaders, and selected community members could enhance use of maternal and child health services. Women who received health information from people they trust are more likely to access and use health services

[33]. Social trust has positive association with better health and safety of a community. Neighborhoods with higher levels of social trust experience lower rates of health and health related problems, and have fewer signs of physical disorder, making residents of these neighborhoods feel safer [34-37].

Despite studies in India [24,38], Tanzania [39] and Cameroon[40] countries indicated the role of SC in improving uptake of maternal and child health services, some other studies have identified its negative consequences as exclusion of outsiders, excess claims on group members, restrictions on individual freedoms, and downward leveling norms [41,42]. To date, there is no study that systematically synthesizes the available literature focusing on social capital's role to improve maternal and child health services use in LMICs. Therefore, this review aimed to synthesize the available literature about the role of social capital on the utilization of maternal and child health services including antenatal care (ANC), institutional delivery and postnatal care (PNC) in LMICs. The findings of the study will inform policy and decision makers to improve maternal and child health services use in LMICs.

\section{Methods}

This systematic review was conducted according to the Joanna Briggs Institute (JBI) manual for mixed evidence synthesis [43]. The protocol was registered with the PROSPERO database (registration number: CRD42021226923). PICO: population (women and children), intervention (social capital), context (Lowand middle-income countries), and outcome (utilization of maternal and child health services).

\section{Inclusion criteria}

In this systematic review, the inclusion criteria were:

- Types of studies: both quantitative and qualitative study designs

- Publication status: both published and unpublished/grey literature

- Language: articles and reports written in English

- Outcome reported: studies that reported on the role of social capital on maternal health services including ANC, institutional delivery and PNC use. The phenomenon of interest for the qualitative component included experiences/views/perceptions of women on the role of social capital on maternal health services use.

- Setting: studies that were conducted in one or more LMICs based on the World Bank criteria

\section{Search and search strategy}

We used Pubmed, Scopus and Science Direct data bases to search articles. In addition, Google Scholar and Google search engines were used for grey literature. To search literature in databases, several searching techniques were used, for example, the presence of medical subject headings (MeSH), text words and key words in the title or abstract. When we search in Google Scholar and Google search engines, the first 100 hits were included. Moreover, we tried to access literature in websites of international organizations such as world health organization and World Bank.

Our search strategy combined terms related to the four domains: Firstly, the term related to 'social capital' like 'social support' OR 'social trust', 'social network' OR 'community network', OR social cohesion were searched. The second term, 'maternal and child health services', comprised 'antenatal care' OR health facility delivery OR postnatal care. The third term, 'utilization' contained utilization OR access OR use OR uptake. Then, countries in 'LMICs' regions were embraced in the search strategy. All synonym keywords and subject headings were combined with the "OR" Boolean operator. Finally, the four domains including social capital, maternal health services, utilization and LMICs were combined with the Boolean operator "AND". According to the World Bank classification[44], articles were chosen for review if they were conducted in LMICs, measured social capital or related terms as an exposure and one or more of the maternal and child health services as an outcome of interest. (Appendix 1)

\section{Study selection}

The literature search was conducted by EWM. On completion, titles and abstracts of the papers identified were reviewed. All retrieved records were downloaded into EndNote, stored and categorized by database of origin. Potential duplicates were removed. Reviewers (EWM and DAZ) independently applied the inclusion criteria to all titles. All papers that appeared to meet the inclusion criteria or where there was uncertainty were taken through to the next stage of full text review. Any disagreements on article exclusion or inclusion were resolved by consensus.

\section{Data extraction and management}

Data were extracted from articles or reports using an excel sheet. The main information collected from each study contain last name of author(s), year of publication, study methods (study setting, study participants, study design, the year of data collection, sample size and data analysis), key findings and limitation acknowledged by the author(s) of the study.

\section{Data Synthesis}

We performed textual narrative synthesis due to lack of uniformity on the definition and measurement of social capital and dependent variables. The characteristics, key significant findings, and limitation of the individual studies were presented in tables. The qualitative findings were synthesized using metaaggregation. The pooled findings were first grouped into categories defined by their similarity of meaning and then combined into one or more synthesized finding(s) that captured their meaning.

\section{Methodological quality assessment}


Quantitative and qualitative components of mixed methods studies selected for retrieval were assessed by two independent reviewers (EWM and DAZ) for methodological validity prior to inclusion in the review using standardized critical appraisal instrument.

Authors of papers were contacted to request additional data for clarification, where required. Any disagreements that arise between the reviewers will be resolved through discussion. The results of critical appraisal were reported in narrative form and in a table.

\section{Results}

\section{Characteristics of the studies}

A total of 1,545 studies were identified by searching databases and other search engines to synthesize evidence about the role of social capital on utilization of maternal health services in LMICs, of which, 328 records were removed due to duplication. Then, 13 records were selected after reading titles, abstracts and full texts. Of these eligible studies, six studies $[24,38-40,45,46]$ were included for quantitative synthesis and seven $[33,47-50]$ of them for qualitative synthesis. This systematic review followed the four-phase flow diagram, Preferred Reporting Items for Systematic Reviews and Meta-Analyses (PRISMA) Statement [51]. (Fig. 1)

Of the six quantitative cross-sectional studies, five[24, 38, 40,45,46] were rated as moderate quality and one[39] was rated high quality. Four out of six studies undertook systematic random sampling in selecting their study participants. The samples taken for the study were representative and outcomes were measured using reliable methods. All of the six studies assessed their outcome using objective measures through proxy questions; controlled confounding factors using multivariate and multivariable regression analysis and did not describe those participants who withdraw or refused to participant in the study.

Of the seven qualitative studies, six [33, 48-50,52,53] were assessed as high quality, and one [47] was assessed as moderate quality. All seven of these studies lacked description of the congruency between the philosophical perspectives and research methodology used. Failure to describe how the researchers' perspectives may have influenced the analysis and interpretation of findings was identified as the main weakness in these qualitative studies, potentially undermining credibility. (Appendix 2)

In this review, studies showed that the concept of social capital had multiple dimensions. Some studies assessed both structural and cognitive social capital. Other studies also examined bonding and bridging dimensions. Related to measurement tools for SC, studies used different types of measurement tools. The variations among tools in its content indicated that instruments for measuring social capital are at the developmental stage.

\section{Statistical analysis}

According to the nature of variables and objectives to be measured, several researchers employed various analysis techniques for both quantitative and qualitative studies. Exploratory factor analysis (EFA) was used to develop and validate a tool for measuring SC and investigate the influence of sociocontextual variables [24, 54-58]. In addition, confirmative factor analysis (CFA) indicated the reliability and validity of social capital scales [55, 59]. Furthermore, regression analyses including multiple hierarchical linear regression [60], multilevel models [24, 38, 61], multivariate regression [62, 63], multiple linear regression and logistic regressions $[45,64,65]$ were used to examine the relationship between social capital and the outcome variables.

\section{Role of social capital on utilization of maternal and child health services}

Of six reviewed quantitative studies, five of them addressed the relationship between social capital and health facility delivery or professional delivery care. The studies in India examined the association of women's participation in community networks known as self-help group/SHG/ and utilization of maternal health services. One of the studies showed that women from villages with a SHG were more likely to give birth in a health facility [45]. In contrast, other study reported that SHG was not statistically significant; however, the presence of SHGs in the community was appreciated for delivering health care messages within and beyond the group [66]. (Table 1)

Three of the six studies focused on the association between social capital and the utilization of antenatal care. Women who lived in communities with higher membership in groups that help form intergroup bridging ties had higher odds of antenatal care use, whereas women who lived in communities with higher intragroup bonding ties and collective efficacy had lower odds of antenatal care use [24]. Besides, male partners' involvement in maternal health care during pregnancy has benefits on maternal health care services access and utilization. The odds of having at least one ANC was higher in women whose male partners' involvement scores were higher [46]. In general, utilization of maternal and child health services which includes antenatal services, institutional delivery and postnatal services were positively associated with number of contacts with health workers during pregnancy [66] and social capital [40].

Qualitative studies conducted in Ethiopia [33], India [47, 48], Ghana [49] and Kenya [50] revealed that all women received some form of emotional, informational and instrumental support from their network members during pregnancy and child birth [49]. Besides, receiving health information from trusted people and socio-cultural factors influenced use of maternal and child health services $[33,50]$. Mothers-in-law play a crucial role in the utilization of ANC in Nepal. Most of them are illiterate, had not used ANC previously and often discouraged their daughters-in-law from attending ANC services. In most cases, mothers-in-law seemed not to be in favor of ANC and played a negative role. "My mother-in-law doesn't help me. It might be due to her past experiences. She used to do all the work by herself during her time of pregnancy. So she wants me to do the same. I have lots of work here at home, so I don't go for ANC checkups" (Non-user Woman 4) [52]. (Table 3)

\section{Discussion}

This study aimed to synthesize the available literature about the role of social capital on the utilization of maternal and child health services in LMICs. Women's social capital had great contribution on the utilization of maternal health service including ANC, health facility delivery and PNC. Women from 
villages with a SHG were more likely to give birth in a health facility [45]. Similarly, the qualitative component of this review revealed that it is socially normative for in-laws, particularly mother in laws, mothers and grandmothers to advice women and provides suggestions on how to experience safe pregnancy and delivery. Pregnant women received some form of emotional, informational and instrumental support from their network members [49].

On the other hand, socio-cultural factors might hinder utilization of maternal health services. In some communities, women have to stay indoors for a month to 40 days; some members of the community cannot go to the hospital for health care services for whatever problem without first going to herbalists; only opting for a facility delivery if complications arise during the birthing process and TBA play a critical role in the decision-making pathway for choice of place of delivery [50]. In line with these findings, a previous systematic review reported that influence of traditional beliefs and sociocultural norms was high during childbirth. Women interpreted their expectations through the lens of family birth stories and social norms [68].

There is no single universally accepted measurement tool for social capital that indicates the tools are in the early stages of development. However, it can be measured at both individual and community levels [30] using quantitative tools [69]. Most reviewed studies assessed both structural and cognitive SC. Structural SC measured using multiple components including individuals' or groups' participation in neighborhood, public civic activities, networks, organizations, associations and institutions, support from individuals and groups, frequency and breadth of community participation [55-57, 60-65, 70-72]. In the case of cognitive SC, it considered trust, values, norms, attitudes toward social interaction, perceptions about participation, beliefs, civic responsibility, altruism, system connection, solidarity, social harmony, social cohesion, strength of civic associations, sharing, collective action and cooperation, information and communication, family role in community, family relationships, sense of fairness or belonging and reciprocity within a community [55-58, $60-65,70-$ 75]. These findings are consistent with other similar systematic reviews [76-79].

\section{Strengths and limitations of the review}

The current review has its own strengths and limitations. One of the strength is inclusion of both quantitative and qualitative studies. A wide range of evidence in systematic review offer policy makers to have more comprehensive overview into factors that cannot be captured through quantitative studies [80, 81]. In addition, we employed a number of search strategies to access relevant studies from databases and hand searching of relevant websites. Regarding the limitations, there is no accepted definition and uniform measurement tool for social capital across the studies which results a challenge to synthesize studies. Also, some studies have no information about the validity and reliability of social capital measurement tool. Moreover, studies with statistically significant findings are more likely to be published. Due to this reason, some studies are missed that results publication bias.

\section{Implication for public policy makers and researchers}

The evidence in this review showed that SC has an impact on utilization of maternal and child health services. So, it will be helpful for policy makers to design strategies on strengthening SC of the community that enhances uptake of ANC, health facility delivery and PNC. However, the pathways for SC and which socio-cultural contexts affect it were not as such investigated. Moreover, the measurement of SC is still in its infancy stage. Hence, further research is required to fill these gaps.

\section{Conclusions}

Social capital has great contribution on utilization of maternal and child health services including ANC, health facility delivery and PNC even though sociocultural factors influence it. Measurement tools for SC have no uniformity across studies and most of them were conducted using a cross-sectional design. Hence, further longitudinal and interventional studies should be employed to pin down direction of causality.

\section{Abbreviations}

ANC: Antenatal care; FGDs: Focus group discussions; IDI: In-depth interviews; JBI: Joanna Briggs institute; LMICs: Low- and middle- income countries; MCH: Maternal and child health services; PNC: Postnatal care; PRISMA: Preferred Reporting Items for Systematic Reviews and Meta-Analyses; SC: Social capital; SDGs: Sustainable developmental goals; SHG: Self-help group; TBA: Traditional birth attendant

\section{Declarations}

\section{Consent for publication}

Not applicable.

\section{Availability of data and materials}

Not applicable (systematic review using data published in primary studies).

\section{Competing interests}

The authors declare that they have no competing interests.

\section{Funding}

No founding used for this study. 
EWM conducted the searches of the literature, screened titles, abstracts and full text of articles, extracted and interpreted data and wrote the first draft of the manuscript. DAZ conduced secondary screening of titles, abstracts and full text of articles, checked data extracted by EWM, and assisted with writing of the manuscript. GDA, YA and GAT assisted with writing the manuscript. All authors read and approved the final manuscript.

\section{References}

1. World Health Organization: Trends in matemal mortality 2000 to 2017: estimates by WHO, UNICEF, UNFPA, World Bank Group and the United Nations Population Division. 2019.

2. Tessema GA, Laurence CO, Melaku YA, Misganaw A, Woldie SA, Hiruye A, Amare AT, Lakew Y, Zeleke BM, Deribew A: Trends and causes of maternal mortality in Ethiopia during 1990-2013: findings from the Global Burden of Diseases study 2013. BMC public health 2017, 17(1):160.

3. Wang H, Abbas KM, Abbasifard M, Abbasi-Kangevari M, Abbastabar H, Abd-Allah F, Abdelalim A, Abolhassani H, Abreu LG, Abrigo MR: Global age-sexspecific fertility, mortality, healthy life expectancy (HALE), and population estimates in 204 countries and territories, 1950-2019: a comprehensive demographic analysis for the Global Burden of Disease Study 2019. The Lancet 2020, 396(10258):1160-1203.

4. Hug L, Alexander M, You D, Alkema L, for Child Ul-aG: National, regional, and global levels and trends in neonatal mortality between 1990 and 2017 , with scenario-based projections to 2030: a systematic analysis. The Lancet Global Health 2019, 7(6):e710-e720.

5. Ruducha J, Mann C, Singh NS, Gemebo TD, Tessema NS, Baschieri A, Friberg I, Zerfu TA, Yassin M, Franca GA: How Ethiopia achieved Millennium Development Goal 4 through multisectoral interventions: a Countdown to 2015 case study. The Lancet Global Health 2017, 5(11):e1142-e1151.

6. Memirie ST, Verguet S, Norheim OF, Levin C, Johansson KA: Inequalities in utilization of maternal and child health services in Ethiopia: the role of primary health care. BMC health services research 2016, 16(1):51

7. Banke-Thomas OE, Banke-Thomas AO, Ameh CA: Factors influencing utilisation of maternal health services by adolescent mothers in Low-and middleincome countries: a systematic review. BMC pregnancy and childbirth 2017, 17(1):65.

8. De Silva MJ, Harpham T: Maternal social capital and child nutritional status in four developing countries. Health \& place 2007, 13(2):341-355.

9. Fantahun M, Berhane $Y$, Wall S, Byass $P$, Högberg U: Women's involvement in household decision-making and strengthening social capital-crucial factors for child survival in Ethiopia. Acta paediatrica 2007, 96(4):582-589.

10. Tekelab T, Chojenta C, Smith R, Loxton D: Factors affecting utilization of antenatal care in Ethiopia: A systematic review and meta-analysis. PloS one 2019, 14(4):e0214848.

11. Ketemaw A, Tareke M, Dellie E, Sitotaw G, Deressa Y, Tadesse G, Debalkie D, Ewunetu M, Alemu Y, Debebe D: Factors associated with institutional delivery in Ethiopia: a cross sectional study. BMC health services research 2020, 20(1):1-6.

12. Geremew AB, Boke MM, Yismaw AE: The Effect of Antenatal Care Service Utilization on Postnatal Care Service Utilization: A Systematic Review and Metaanalysis Study. Journal of Pregnancy 2020, 2020

13. Oduse S, Zewotir T, North D: The impact of antenatal care on under-five mortality in Ethiopia: a difference-in-differences analysis. $B M C$ pregnancy and childbirth 2021, 21(1):1-9.

14. Berhe R, Nigusie A: Magnitude of home delivery and associated factors among child bearing age mothers in Sherkole District, Benishangul Gumuz regional state-Western-Ethiopia. BMC public health 2020, 20:1-7.

15. Ferlander S: The importance of different forms of social capital for health. Acta sociologica 2007, 50(2):115-128.

16. Chandran A, Benning L, Musci RJ, Wilson TE, Milam J, Adedimeji A, Parish C, Adimora AA, Cocohoba J, Cohen MH: The longitudinal association between social support on HIV medication adherence and healthcare utilization in the Women's Interagency HIV Study. AIDS and Behavior 2019, 23(8):2014-2024.

17. Engbers TA, Thompson MF, Slaper TF: Theory and measurement in social capital research. Social Indicators Research 2017, 132(2):537-558.

18. Ichiro Kawachi, Bruce P Kennedy, EdD KL, Deborah Prothrow-Stith: Social Capital, Income Inequality, and Mortality. 1997.

19. Flores EC, Fuhr DC, Bayer AM, Lescano AG, Thorogood N, Simms V: Mental health impact of social capital interventions: a systematic review. Social psychiatry and psychiatric epidemiology 2018, 53(2):107-119.

20. Putnam R: The prosperous community: Social capital and public life. The american prospect 1993, 13(Spring, Vol. 4. ).

21. Coleman JS: Social capital in the creation of human capital. American journal of sociology 1988, 94:S95-S120.

22. Bourdieu P: The levels of social capital. Handbook of theory of research for the sociology of education 1985:241-258.

23. Eriksson $\mathrm{M}, \mathrm{Ng} \mathrm{N}$ : Changes in access to structural social capital and its influence on self-rated health over time for middle-aged men and women: a longitudinal study from northern Sweden. Social Science \& Medicine 2015, 130:250-258.

24. Story WT: Social capital and the utilization of maternal and child health services in India: a multilevel analysis. PloS one 2014, 28:73-84.

25. Grootaert C, Narayan D, Jones VN, Woolcock M: Measuring social capital: An integrated questionnaire: The World Bank; 2004.

26. Terrion JL: Building social capital in vulnerable families: Success markers of a school-based intervention program. Youth \& Society 2006, 38(2):155-176.

27. Putnam RD: Bowling alone: America's declining social capital. In: Culture and politics. edn.: Springer; 2000: $223-234$.

28. Bharathi Palanisamy, Kalpana Kosalram, Gopichandran V: Dimensions of social capital of families with thalassemia in an indigenous population in Tamil Nadu, India - a qualitative study 2017.

29. Jiang N, Wu B, Lu N, Dong T: Neighborhood-based social capital and cognitive function among older adults in five low-and middle-income countries: Evidence from the World Health Organization Study on global AGEing and adult health. International journal of geriatric psychiatry 2020, 35(4):365-375. 
30. De Silva MJ, Huttly SR, Harpham T, Kenward MG: Social capital and mental health: a comparative analysis of four low income countries. Social science \& medicine 2007, 64(1):5-20.

31. Abebe A, Kebede W, Alemie A: Roles of Ego Social Networks for Community Development in Southern Ethiopia: The Case of Tullo Community. The International Journal of Community and Social Development 2019, 1(4):332-349.

32. Szreter S, Woolcock M: Health by association? Social capital, social theory, and the political economy of public health International Journal of Epidemiology 2004, 33:650-667.

33. Mamo A, Morankar S, Asfaw S, Bergen N, Kulkarni MA, Abebe L, Labonté R, Birhanu Z, Abera M: How do community health actors explain their roles? Exploring the roles of community health actors in promoting matemal health services in rural Ethiopia. BMC health services research 2019, $19(1): 724$.

34. Flynn K, Richmond TS, Branas CC, Wiebe DJ: Neighbourhood social trust and youth perceptions of safety during daily activities. Injury Prevention 2018, 24(6):445-447.

35. Hipp JR, Wickes R: Violence in urban neighborhoods: A longitudinal study of collective efficacy and violent crime. Journal of Quantitative Criminology 2017, 33(4):783-808.

36. Sampson RJ: The neighborhood context of well-being. Perspectives in biology and medicine 2003, 46(3):S53-S64.

37. Legewie J: Living on the edge: neighborhood boundaries and the spatial dynamics of violent crime. Demography 2018, 55(5):1957-1977.

38. Singh PK, Kumar C, Rai RK, Singh L: Factors associated with maternal healthcare services utilization in nine high focus states in India: a multilevel analysis based on 14385 communities in 292 districts. Health policy and planning 2014, 29(5):542-559.

39. Semali IA, Leyna GH, Mmbaga EJ, Tengia-Kessy A: Social capital as a determinant of pregnant mother's place of delivery: experience from Kongwa District in Central Tanzania. PloS one 2015, 10(10):e0138887.

40. McTavish S, Moore S: On est ensemble: social capital and maternal health care use in rural Cameroon. Globalization and health 2015, 11(1):33.

41. Portes A: Social Capital: Its Origins and Applications in Modern Sociology. Annual Review of Sociology 1998, 24(1):1-24.

42. Villalonga-Olives E, Kawachi I: The dark side of social capital: A systematic review of the negative health effects of social capital. Social Science \& Medicine 2017, 194:105-127

43. Aromataris E, Munn Z: JBI manual for evidence synthesis. JBI; 2020. In.; 2020.

44. Fantom N, Serajuddin U: The World Bank's classification of countries by income: The World Bank; 2016.

45. Saha S, Annear PL, Pathak S: The effect of Self-Help Groups on access to maternal health services: evidence from rural India. International journal for equity in health $2013,12: 36$.

46. Mohammed BH, Johnston JM, Vackova D, Hassen SM, Yi H: The role of male partner in utilization of matemal health care services in Ethiopia: a community-based couple study. BMC pregnancy and childbirth 2019, 19(1):28.

47. Papp SA, Gogoi A, Campbell C: Improving maternal health through social accountability: a case study from Orissa, India. Global public health 2013, 8(4):449-464.

48. Raman S, Srinivasan K, Kurpad A, Dwarkanath P, Ritchie J, Worth H: 'My mother...my sisters... and my friends': sources of maternal support in the perinatal period in urban India. Midwifery 2014, 30(1):130-137.

49. Cofie LE, Barrington C, Sodzi-Tettey S, Ennett S, Maman S, Singh K: A qualitative study of women's network social support and facility delivery in rural Ghana. PloS one 2018, 13(11):e0206429.

50. Mochache V, Wanje G, Nyagah L, Lakhani A, El-Busaidy H, Temmerman M, Gichangi P: Religious, socio-cultural norms and gender stereotypes influence uptake and utilization of maternal health services among the Digo community in Kwale, Kenya: a qualitative study. Reproductive health 2020, 17 (1):71.

51. Moher D, Liberati A, Tetzlaff J, Altman DG, Group P: Preferred reporting items for systematic reviews and meta-analyses: the PRISMA statement. PLoS med 2009, 6(7):e1000097.

52. Simkhada B, Porter MA, Van Teijlingen ER: The role of mothers-in-law in antenatal care decision-making in Nepal: a qualitative study. BMC pregnancy and childbirth 2010, 10(1):1-10.

53. Sapkota S, Kobayashi T, Takase M: Husbands' experiences of supporting their wives during childbirth in Nepal. Midwifery 2012, 28(1):45-51.

54. Agampodi TC, Agampodi SB, Glozier N, Lelwala T, Sirisena K, Siribaddana S: Development and validation of the Social Capital Assessment Tool in pregnancy for Matemal Health in Low and middle income countries (LSCAT-MH). BMJ open 2019, 9(7):e027781.

55. De Silva MJ, Harpham T, Tuan T, Bartolini R, Penny ME, Huttly SR: Psychometric and cognitive validation of a social capital measurement tool in Peru and Vietnam. Social science \& medicine 2006, 62(4):941-953.

56. Mitchell AD, Bossert TJ: Measuring dimensions of social capital: Evidence from surveys in poor communities in Nicaragua. Social Science \& Medicine 2007, 64(1):50-63.

57. Looman WS, Farrag S: Psychometric properties and cross-cultural equivalence of the Arabic Social Capital Scale: Instrument development study. International journal of nursing studies 2009, 46(1):45-54.

58. Moscardino U, Scrimin S, Capello F, Altoè G: Social support, sense of community, collectivistic values, and depressive symptoms in adolescent survivors of the 2004 Beslan terrorist attack. Social Science \& Medicine 2010, 70(1):27-34.

59. Wang P, Chen X, Gong J, Jacques-Tiura AJ: Reliability and validity of the personal social capital scale 16 and personal social capital scale 8 : Two short instruments for survey studies. Social Indicators Research 2014, 119(2):1133-1148.

60. Thuy NTM, Berry HL: Social capital and mental health among mothers in Vietnam who have children with disabilities. Global health action 2013, 6(1):18886. 
61. Friche A, Diez-Roux A, César C, Xavier C, Proietti F, Caiaffa W: Assessing the psychometric and ecometric properties of neighborhood scales in developing countries: Saúde em Beagá Study, Belo Horizonte, Brazil, 2008-2009. Journal of urban health 2013, 90(2).

62. Borges CM, Campos ACV, Vargas AD, Ferreira EF, Kawachi I: Social capital and self-rated health among adolescents in Brazil: an exploratory study. BMC research notes 2010, 3(1):1-6.

63. Pronyk PM, Harpham T, Morison LA, Hargreaves JR, Kim JC, Phetla G, Watts CH, Porter JD: Is social capital associated with HIV risk in rural South Africa? Social science \& medicine 2008, 66(9):1999-2010.

64. Harpham T, De Silva MJ, Tuan T: Maternal social capital and child health in Vietnam. Journal of Epidemiology \& Community Health 2006, 60(10):865871.

65. Brune NE, Bossert T: Building social capital in post-conflict communities: Evidence from Nicaragua. Social Science \& Medicine 2009, 68(5):885-893.

66. Singh R, Neogi SB, Hazra A, Irani L, Ruducha J, Ahmad D, Kumar S, Mann N, Mavalankar D: Utilization of maternal health services and its determinants: a cross-sectional study among women in rural Uttar Pradesh, India. Journal of Health, Population and Nutrition 2019, 38(1):13.

67. Sheikh MR, Ali SZ, Hussain A, Shehzadi R, Afzal MM: Measurement of social capital as an indicator of community-based initiatives (CBI) in the Islamic Republic of Iran. Journal of health organization and management 2009.

68. Downe S, Finlayson K, Oladapo O, Bonet M, Gülmezoglu AM: What matters to women during childbirth: a systematic qualitative review. PloS one 2018, 13(4):e0194906.

69. Kawachi I, Subramanian SV, Kim D: Social capital and health. In: Social capital and health. edn.: Springer; 2008: 1-26.

70. Harpham T, Grant E, Thomas E: Measuring social capital within health surveys: key issues. Health policy and planning 2002, 17(1):106-111.

71. Ashrafi E, Montazeri A, Mousavi M, Vaez-Mahdavi M, Asadi-Lari M: Influence of sociodemographic features and general health on social capital: Findings from a large population-based survey in Tehran, Iran (Urban-HEART). Public health 2012, 126(9):796-803.

72. Hurtado D, Kawachi I, Sudarsky J: Social capital and self-rated health in Colombia: the good, the bad and the ugly. Social Science \& Medicine 2011, 72(4):584-590

73. de Souza EM, Grundy E: Intergenerational interaction, social capital and health: results from a randomised controlled trial in Brazil. Social science \& medicine 2007, 65(7):1397-1409.

74. Wang H, Schlesinger M, Wang H, Hsiao WC: The flip-side of social capital: the distinctive influences of trust and mistrust on health in rural China. Social Science \& Medicine 2009, 68(1):133-142.

75. Modie-Moroka T: Does level of social capital predict perceived health in a community?-a study of adult residents of low-income areas of Francistown, Botswana. Journal of health, population, and nutrition 2009, 27(4):462.

76. Ehsan AM, De Silva MJ: Social capital and common mental disorder: a systematic review. J Epidemiol Community Health 2015, 69(10):1021-1028.

77. Villalonga-Olives E, Wind T, Kawachi I: Social capital interventions in public health: a systematic review. Social Science \& Medicine 2018, 212:203-218.

78. Story WT: Social capital and health in the least developed countries: a critical review of the literature and implications for a future research agenda. Global public health 2013, 8(9):983-999.

79. Agampodi TC, Agampodi SB, Glozier N, Siribaddana S: Measurement of social capital in relation to health in low and middle income countries (LMIC): a systematic review. Social science \& medicine 2015, 128:95-104.

80. Dixon-Woods M, Agarwal S, Jones D, Young B, Sutton A: Synthesising qualitative and quantitative evidence: a review of possible methods. Journal of health services research \& policy 2005, 10(1):45-53.

81. Mays N, Pope C, Popay J: Systematically reviewing qualitative and quantitative evidence to inform management and policy-making in the health field. Journal of health services research \& policy 2005, 10(1_suppl):6-20.

82. The Joanna Briggs Institute: Joanna Briggs Institute Reviewers' Manual 2014 Edition. Adelaide: The Joanna Briggs Institute; 2014.

\section{Tables}


Table 1

Quantitative studies included in a systematic review of social capital and maternal health services in LMICS

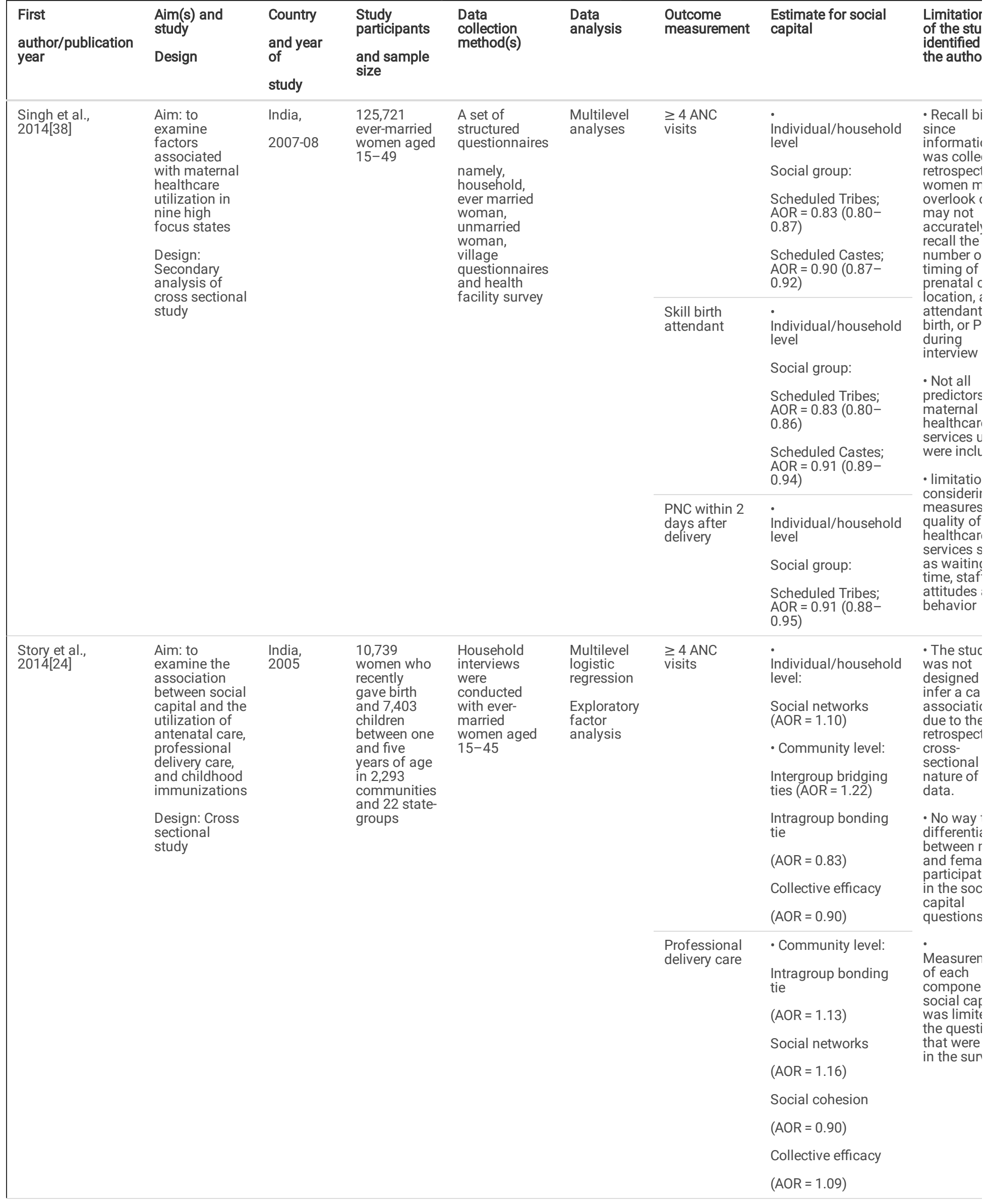




\begin{tabular}{|c|c|c|c|c|c|c|c|c|}
\hline $\begin{array}{l}\text { First } \\
\text { author/publication } \\
\text { year }\end{array}$ & $\begin{array}{l}\text { Aim(s) and } \\
\text { study } \\
\text { Design }\end{array}$ & $\begin{array}{l}\text { Country } \\
\text { and year } \\
\text { of } \\
\text { study }\end{array}$ & $\begin{array}{l}\text { Study } \\
\text { participants } \\
\text { and sample } \\
\text { size }\end{array}$ & $\begin{array}{l}\text { Data } \\
\text { collection } \\
\text { method(s) }\end{array}$ & $\begin{array}{l}\text { Data } \\
\text { analysis }\end{array}$ & $\begin{array}{l}\text { Outcome } \\
\text { measurement }\end{array}$ & $\begin{array}{l}\text { Estimate for social } \\
\text { capital }\end{array}$ & $\begin{array}{l}\text { Limitatiol } \\
\text { of the stu } \\
\text { identified } \\
\text { the autho }\end{array}$ \\
\hline $\begin{array}{l}\text { Semali et al., } \\
2015[39]\end{array}$ & $\begin{array}{l}\text { Aim: to } \\
\text { determine the } \\
\text { role of social } \\
\text { capital in } \\
\text { facilitating } \\
\text { health facility } \\
\text { delivery } \\
\text { Design: } \\
\text { Community } \\
\text { based cross } \\
\text { sectional } \\
\text { study }\end{array}$ & $\begin{array}{l}\text { Tanzania, } \\
2015\end{array}$ & $\begin{array}{l}744 \text { mothers } \\
\text { with children } \\
\text { aged less } \\
\text { than five } \\
\text { years }\end{array}$ & $\begin{array}{l}\text { Validated } \\
\text { World Bank's } \\
\text { social capital } \\
\text { assessment } \\
\text { tool was used } \\
\text { [67]. } \\
\text { Questionnaire } \\
\text { administered } \\
\text { in face-to face } \\
\text { interviews. }\end{array}$ & $\begin{array}{l}\text { Multilevel } \\
\text { analysis } \\
\text { and } \\
\text { Principal } \\
\text { Component } \\
\text { Analysis } \\
\text { (PCA) }\end{array}$ & $\begin{array}{l}\text { Health } \\
\text { facility } \\
\text { delivery }\end{array}$ & $\begin{array}{l}\text { Social capital } \\
\text { quintiles: } \\
\text { Lowest; } \text { AOR = } 2.9 \\
(1.4-6.1) \\
\text { Moderate, AOR = } 5.5 \\
(2.3-13.3) \\
\text { High; AOR = } 4.7 \text { (1.9- } \\
\text { 11.6) } \\
\text { Highest; AOR = } 5.6 \\
(2.4-13.4)\end{array}$ & $\begin{array}{l}\text { Mothers v } \\
\text { survived t } \\
\text { birth proc } \\
\text { and henci } \\
\text { introduce } \\
\text { bias whic } \\
\text { might hai } \\
\text { overestim } \\
\text { the rate o } \\
\text { facility } \\
\text { deliveries }\end{array}$ \\
\hline $\begin{array}{l}\text { Saha et al., } \\
\text { 2013[45] }\end{array}$ & $\begin{array}{l}\text { Aim: to } \\
\text { analyze the } \\
\text { impact of self- } \\
\text { help groups on } \\
\text { maternal } \\
\text { health service } \\
\text { uptake at } \\
\text { national level } \\
\text { Design: } \\
\text { secondary } \\
\text { analysis of } \\
\text { cross sectional } \\
\text { study }\end{array}$ & $\begin{array}{l}\text { India, } \\
2013\end{array}$ & $\begin{array}{l}643,944 \text { ever } \\
\text { married } \\
\text { women }(15- \\
49 \text { years) }\end{array}$ & $\begin{array}{l}\text { Data was } \\
\text { collected } \\
\text { through self- } \\
\text { reported } \\
\text { information } \\
\text { from } \\
\text { respondents }\end{array}$ & $\begin{array}{l}\text { Forward } \\
\text { stepwise } \\
\text { logistic } \\
\text { regression } \\
\text { model }\end{array}$ & $\begin{array}{l}\text { Institutional } \\
\text { delivery }\end{array}$ & $\begin{array}{l}\text { Presence of self-help } \\
\text { group }(\mathrm{SHG}): \text { AOR = } \\
1.19(1.13-1.24)\end{array}$ & 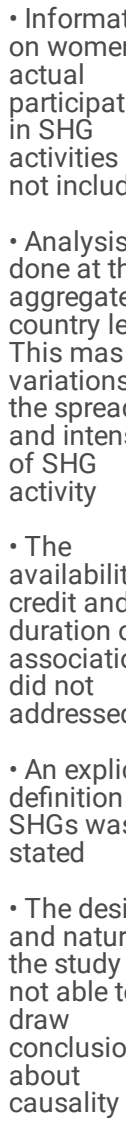 \\
\hline \multirow[t]{2}{*}{$\begin{array}{l}\text { Mohammed et al., } \\
\text { 2019[46] }\end{array}$} & $\begin{array}{l}\text { Aim: to } \\
\text { examine the } \\
\text { association } \\
\text { between male } \\
\text { partners' } \\
\text { involvement in } \\
\text { maternal } \\
\text { health care on } \\
\text { utilization of } \\
\text { maternal } \\
\text { health care } \\
\text { services }\end{array}$ & $\begin{array}{l}\text { Ethiopia, } \\
2014\end{array}$ & $\begin{array}{l}210 \\
\text { male/female } \\
\text { couples with } \\
\text { a baby less } \\
\text { than } 6 \\
\text { months old }\end{array}$ & $\begin{array}{l}\text { Two } \\
\text { structured } \\
\text { questionnaires } \\
\text { were used to } \\
\text { collect the } \\
\text { data from } \\
\text { men and } \\
\text { women }\end{array}$ & $\begin{array}{l}\text { Multivariate } \\
\text { logistic } \\
\text { regression } \\
\text { models }\end{array}$ & $\begin{array}{l}\text { Delivery in } \\
\text { health facility }\end{array}$ & $\begin{array}{l}\text { Over all male } \\
\text { partners' } \\
\text { involvement(MPI) } \\
\text { scale score: AOR = } \\
1.61(1.05-2.45) \\
\text { Over all male } \\
\text { partners' } \\
\text { involvement(MPI) } \\
\text { scale score: AOR = } \\
1.22(1.01-1.48)\end{array}$ & $\begin{array}{l}\text { Self-repor } \\
\text { might } \\
\text { introduce } \\
\text { social } \\
\text { desirabilit } \\
\text { bias }\end{array}$ \\
\hline & $\begin{array}{l}\text { Design: } \\
\text { community- } \\
\text { based cross- } \\
\text { sectional } \\
\text { study }\end{array}$ & & & & & & & \\
\hline
\end{tabular}




\begin{tabular}{|c|c|c|c|c|c|c|c|c|}
\hline $\begin{array}{l}\text { Firstavish et al., } \\
2015[40] \\
\text { author/publication } \\
\text { year }\end{array}$ & $\begin{array}{l}\text { Aim(s\$) and } \\
\text { studyine the } \\
\text { importance of } \\
\text { Besign } \\
\text { networks and } \\
\text { social capital } \\
\text { in maternal } \\
\text { health care } \\
\text { use }\end{array}$ & $\begin{array}{l}\text { Countron, } \\
2009 \\
\text { and year } \\
\text { of } \\
\text { study }\end{array}$ & $\begin{array}{l}\text { \$tudyomen } \\
\text { pantieipants- } \\
45 \text { years old } \\
\text { amd sample } \\
\text { gizen birth at } \\
\text { any time in } \\
\text { the five } \\
\text { years prior }\end{array}$ & $\begin{array}{l}\text { Pataiews } \\
\text { collection } \\
\text { epefthod(sd) }\end{array}$ & $\begin{array}{l}\text { Pateson } \\
\text { axgalysjison } \\
\text { and } \\
\text { inductive } \\
\text { content } \\
\text { analysis }\end{array}$ & 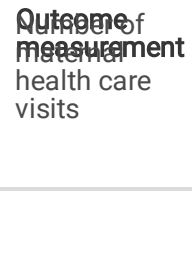 & $\begin{array}{l}\text { Estimateresosesial } \\
\text { calperitadducation) } \\
\text { Incidence rate } \\
\text { ratios(IRR) = } \\
1.13(1.02-1.26)\end{array}$ & 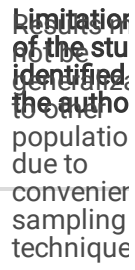 \\
\hline & $\begin{array}{l}\text { Design: cross- } \\
\text { sectional } \\
\text { study }\end{array}$ & & & & & & & \\
\hline
\end{tabular}


Table 2

Qualitative studies included in the review of the role of social capital on maternal and child health services use in LMICs

\begin{tabular}{|c|c|c|c|c|c|c|c|c|}
\hline $\begin{array}{l}\text { First } \\
\text { author/publication } \\
\text { year }\end{array}$ & $\begin{array}{l}\text { Aim(s) and } \\
\text { study } \\
\text { Design }\end{array}$ & $\begin{array}{l}\text { Country } \\
\text { and year } \\
\text { of } \\
\text { study }\end{array}$ & $\begin{array}{l}\text { Study } \\
\text { participants } \\
\text { and sample } \\
\text { size }\end{array}$ & $\begin{array}{l}\text { Data collection } \\
\text { method(s) and } \\
\text { analysis }\end{array}$ & $\begin{array}{l}\text { Social capital } \\
\text { measures }\end{array}$ & $\begin{array}{l}\text { Description of } \\
\text { social capital } \\
\text { findings }\end{array}$ & $\begin{array}{l}\text { Limitation(s) } \\
\text { of the study } \\
\text { identified by } \\
\text { the author(s) }\end{array}$ & $\begin{array}{l}\text { Que } \\
\text { sco }\end{array}$ \\
\hline $\begin{array}{l}\text { Cofie et al., } \\
2018[49]\end{array}$ & $\begin{array}{l}\text { Aim: to examine } \\
\text { the social } \\
\text { network } \\
\text { dynamics of all } \\
\text { members of } \\
\text { women's social } \\
\text { networks during } \\
\text { pregnancy and } \\
\text { childbirth } \\
\text { Design: } \\
\text { Phenomenology }\end{array}$ & $\begin{array}{l}\text { Ghana, } \\
2015\end{array}$ & $\begin{array}{l}\cdot \text { Mothers ( } \mathrm{n}= \\
40 \text { ) } \\
\text { • Husbands ( } \mathrm{n} \\
=20 \text { ), and } \\
\text { - } 4 \text { focus group } \\
\text { interviews with } \\
\text { mothers-in-law }\end{array}$ & $\begin{array}{l}\text { - In-depth } \\
\text { interviews (IDIs) } \\
\text { - Focus group } \\
\text { discussions(FGDs) } \\
\text { - Data were } \\
\text { analyzed using } \\
\text { narrative } \\
\text { summaries and } \\
\text { thematic coding }\end{array}$ & $\begin{array}{l}\text { Social support } \\
\text { and network: } \\
\text { Network } \\
\text { proximity } \\
\text { Frequency of } \\
\text { contact } \\
\begin{array}{l}\text { Nature of } \\
\text { relationships }\end{array}\end{array}$ & $\begin{array}{l}\text { social networks } \\
\text { contribute in } \\
\text { important ways } \\
\text { to women's use } \\
\text { of facility-based } \\
\text { pregnancy and } \\
\text { delivery care }\end{array}$ & $\begin{array}{l}\text { Translation } \\
\text { errors } \\
\text { recall bias } \\
\text { Response } \\
\text { bias } \\
\text { social } \\
\text { desirability } \\
\text { bias }\end{array}$ & $\mathrm{Higl}$ \\
\hline $\begin{array}{l}\text { Mochache et al., } \\
\text { 2020[50] }\end{array}$ & $\begin{array}{l}\text { Aim: to explore } \\
\text { how individual } \\
\text { and community- } \\
\text { wide factors } \\
\text { influenced } \\
\text { uptake and } \\
\text { utilization of } \\
\text { maternal health } \\
\text { services } \\
\text { Design: } \\
\text { Phenomenology }\end{array}$ & $\begin{array}{l}\text { Kenya, } \\
2015\end{array}$ & $\begin{array}{l}\text { - Female } \\
\text { (pregnant and } \\
\text { postpartum) as } \\
\text { well as male } \\
\text { adult } \\
\text { community } \\
\text { members } \\
\cdot 5 \text { FGDs (N = } \\
47 \text { ) } \\
\cdot 15 \text { IDIs(N = } \\
15)\end{array}$ & $\begin{array}{l}\text { - FGDs stratified } \\
\text { by age and gender; } \\
3 \text { among men and } \\
2 \text { among women, } \\
\text { - IDIs } \\
\text { - A thematic } \\
\text { content analytic } \\
\text { approach was } \\
\text { used }\end{array}$ & $\begin{array}{l}\text { Socio-cultural } \\
\text { norms, religious } \\
\text { norms and } \\
\text { gender } \\
\text { stereotypes }\end{array}$ & $\begin{array}{l}\text { Religious and } \\
\text { socio-cultural } \\
\text { norms as well as } \\
\text { gender } \\
\text { stereotypes } \\
\text { influenced } \\
\text { utilization of } \\
\text { maternal health } \\
\text { services, } \\
\text { including facility- } \\
\text { based delivery }\end{array}$ & $\begin{array}{l}\text { No limitation } \\
\text { information } \\
\text { was provided }\end{array}$ & Higl \\
\hline $\begin{array}{l}\text { Papp et al., } \\
\text { 2013[47] }\end{array}$ & $\begin{array}{l}\text { Aim: to identify } \\
\text { the processes } \\
\text { and psycho- } \\
\text { social pathways } \\
\text { through which } \\
\text { social } \\
\text { accountability } \\
\text { can contribute } \\
\text { to improvement } \\
\text { of maternal } \\
\text { health } \\
\text { Design: case } \\
\text { study }\end{array}$ & $\begin{array}{l}\text { India, } \\
2013\end{array}$ & $\begin{array}{l}\text { - Interviews } \\
\text { with } 4 \text { health } \\
\text { providers, } \\
\text { • } 3 \text { policy- } \\
\text { makers and } \\
\text { government } \\
\text { officials, } \\
\text { • } 4 \text { media } \\
\text { representatives, } \\
\text { •2 } \\
\text { representatives } \\
\text { from partner, } \\
\text {-2 national, } 4 \\
\text { state and } \\
\text { district Central } \\
\text { Statistical } \\
\text { Agency staff, } \\
\text { - } 1 \text { Accredited } \\
\text { social health } \\
\text { activist }\end{array}$ & $\begin{array}{l}\text { Interviews and } \\
\text { focus groups }\end{array}$ & $\begin{array}{l}\text { Critical } \\
\text { consciousness, } \\
\text { social capital } \\
\text { and 'receptive } \\
\text { social spaces' } \\
\text { to outline a } \\
\text { social- } \\
\text { psychological } \\
\text { account of the } \\
\text { pathways } \\
\text { between Social } \\
\text { accountability } \\
\text { and service } \\
\text { effectiveness }\end{array}$ & $\begin{array}{l}\text { Three processes } \\
\text { that underpin } \\
\text { social } \\
\text { accountability: } \\
\text { (1) generating } \\
\text { demand, (2) } \\
\text { leveraging } \\
\text { intermediaries } \\
\text { and (3) } \\
\text { sensitizing } \\
\text { leaders and } \\
\text { health providers } \\
\text { to the needs of } \\
\text { women. }\end{array}$ & $\begin{array}{l}\text { Focused on } \\
\text { the } \\
\text { processes } \\
\text { and psycho- } \\
\text { social } \\
\text { pathways } \\
\text { underpinning } \\
\text { the public } \\
\text { hearings }\end{array}$ & Mor \\
\hline $\begin{array}{l}\text { Raman et al., } \\
2014[48]\end{array}$ & $\begin{array}{l}\text { Aim: to explore } \\
\text { the wide- } \\
\text { ranging sources } \\
\text { of support that } \\
\text { the maternal- } \\
\text { infant dyad } \\
\text { need or expect } \\
\text { throughout the } \\
\text { perinatal period } \\
\text { Design: } \\
\text { qualitative } \\
\text { interviews and } \\
\text { ethnographic } \\
\text { approach. }\end{array}$ & $\begin{array}{l}\text { India, } \\
2008-10\end{array}$ & $\begin{array}{l}\cdot 36 \text { mothers } \\
\text { from different } \\
\text { socio-cultural } \\
\text { and socio- } \\
\text { economic } \\
\text { backgrounds } \\
\text { who had given } \\
\text { birth within the } \\
\text { past two years } \\
\text { in a tertiary } \\
\text { hospital } \\
\text { - } 13 \\
\text { participants in } \\
\text { group one (low } \\
\text { education), } \\
\text { - } 11 \text { in group } \\
\text { two (medium } \\
\text { education) and } \\
\text { - } 12 \text { in group } 3 \\
\text { (high } \\
\text { education). }\end{array}$ & $\begin{array}{l}\cdot \text { IDIs } \\
\text { - Thematic } \\
\text { analysis of } \\
\text { transcribed } \\
\text { interviews } \\
\text { - Ethnographic } \\
\text { field notes was } \\
\text { carried out }\end{array}$ & $\begin{array}{l}\cdot \text { Female } \\
\text { networks } \\
\text { - Extended } \\
\text { family support } \\
\text { - Own mother } \\
\text { emotional } \\
\text { support and } \\
\text { advice }\end{array}$ & $\begin{array}{l}4 \text { themes } \\
\text { emerged: } \\
\text { - Importance of } \\
\text { women's own } \\
\text { mothers } \\
\text { - My place } \\
\text { - Female support } \\
\text { network } \\
\text { - Role of } \\
\text { husband } \\
\text { - The ambivalent } \\
\text { role of the family }\end{array}$ & $\begin{array}{l}\text { No limitation } \\
\text { information } \\
\text { was provided }\end{array}$ & Higl \\
\hline
\end{tabular}




\begin{tabular}{|c|c|c|c|c|c|c|c|c|}
\hline $\begin{array}{l}\text { First } \\
\text { author/publication } \\
\text { year }\end{array}$ & $\begin{array}{l}\text { Aim(s) and } \\
\text { study } \\
\text { Design }\end{array}$ & $\begin{array}{l}\text { Country } \\
\text { and year } \\
\text { of } \\
\text { study }\end{array}$ & $\begin{array}{l}\text { Study } \\
\text { participants } \\
\text { and sample } \\
\text { size }\end{array}$ & $\begin{array}{l}\text { Data collection } \\
\text { method(s) and } \\
\text { analysis }\end{array}$ & $\begin{array}{l}\text { Social capital } \\
\text { measures }\end{array}$ & $\begin{array}{l}\text { Description of } \\
\text { social capital } \\
\text { findings }\end{array}$ & $\begin{array}{l}\text { Limitation(s) } \\
\text { of the study } \\
\text { identified by } \\
\text { the author(s) }\end{array}$ & $\begin{array}{l}\text { Que } \\
\text { sco }\end{array}$ \\
\hline $\begin{array}{l}\text { Mamo et al., } \\
2019 \text { [33] }\end{array}$ & $\begin{array}{l}\text { Aim: to explore } \\
\text { the actual roles, } \\
\text { responsibilities, } \\
\text { and } \\
\text { contribution of } \\
\text { different } \\
\text { community } \\
\text { individuals or } \\
\text { groups in } \\
\text { promoting ANC, } \\
\text { childbirth and } \\
\text { early postnatal } \\
\text { cares. } \\
\text { Design: case } \\
\text { study }\end{array}$ & $\begin{array}{l}\text { Ethiopia, } \\
2016\end{array}$ & $\begin{array}{l}\text { HEWs, religious } \\
\text { leaders, } \\
\text { Women } \\
\text { Developmental } \\
\text { Army leaders, } \\
\text { Male } \\
\text { Developmental } \\
\text { Army leaders } \\
\text { and married } \\
\text { male and } \\
\text { female } \\
\text { community } \\
\text { members }\end{array}$ & $\begin{array}{l}12 \text { FGDs and } \\
24 \text { semi-structured } \\
\text { IDIs }\end{array}$ & $\begin{array}{l}\text { Social support } \\
\text { Provision of } \\
\text { continuous } \\
\text { support } \\
\text { Work as a } \\
\text { community- } \\
\text { health care } \\
\text { system } \\
\text { linkages }\end{array}$ & $\begin{array}{l}\text { Offering social } \\
\text { support } \\
\text { (practical help } \\
\text { with routine } \\
\text { activities, } \\
\text { resources and } \\
\text { material goods, } \\
\text { emotional } \\
\text { support and } \\
\text { assurance, } \\
\text { nutritional } \\
\text { support, and } \\
\text { accompaniment) }\end{array}$ & $\begin{array}{l}\text { - Unable to } \\
\text { explore } \\
\text { information } \\
\text { from zonal } \\
\text { health } \\
\text { officers } \\
\text { - Specific } \\
\text { distance } \\
\text { from a } \\
\text { woman's } \\
\text { residence to } \\
\text { a health } \\
\text { facility were } \\
\text { not explicitly } \\
\text { accounted in } \\
\text { this study } \\
\text { - Social } \\
\text { desirability } \\
\text { bias }\end{array}$ & Higl \\
\hline $\begin{array}{l}\text { Simkhada et al., } \\
\text { 2010[52] }\end{array}$ & $\begin{array}{l}\text { Aim: to explore } \\
\text { the mother-in } \\
\text { law's role in (a) } \\
\text { her daughter-in- } \\
\text { law's ANC } \\
\text { uptake; and (b) } \\
\text { the decision- } \\
\text { making process } \\
\text { about using } \\
\text { ANC services in } \\
\text { Nepal. }\end{array}$ & $\begin{array}{l}\text { Nepal, } \\
2006\end{array}$ & $\begin{array}{l}\text { • } 30 \\
\text { purposively } \\
\text { selected } \\
\text { antenatal or } \\
\text { postnatal } \\
\text { mothers (half } \\
\text { users, half non- } \\
\text { users of ANC), } \\
\text { • } 10 \text { husbands } \\
\text { and } \\
\text { • } 10 \text { mothers-in- } \\
\text { law in two } \\
\text { different (urban } \\
\text { and rural) } \\
\text { communities }\end{array}$ & IDIs & $\begin{array}{l}\text { Communication } \\
\text { and } \\
\text { relationships } \\
\text { between } \\
\text { mothers-in-law } \\
\text { and daughters- } \\
\text { in-law }\end{array}$ & $\begin{array}{l}\text { - Use of ANC is } \\
\text { strongly } \\
\text { influenced by } \\
\text { mothers-in-law's } \\
\text { roles and } \\
\text { attitudes } \\
\text { - Mothers-in-law } \\
\text { appeared to } \\
\text { have less } \\
\text { influence on } \\
\text { ANC uptake if } \\
\text { they did not live } \\
\text { in the same } \\
\text { household as } \\
\text { their daughters- } \\
\text { in-law }\end{array}$ & $\begin{array}{l}\text { - It was not } \\
\text { feasible to } \\
\text { include } \\
\text { literate } \\
\text { mothers-in- } \\
\text { law }\end{array}$ & Higl \\
\hline $\begin{array}{l}\text { Sapkota et al., } \\
2012[53]\end{array}$ & $\begin{array}{l}\text { Aim: to explore } \\
\text { husbands' } \\
\text { experiences of } \\
\text { supporting their } \\
\text { wives during } \\
\text { childbirth }\end{array}$ & $\begin{array}{l}\text { Nepal, } \\
2009\end{array}$ & $\begin{array}{l}\text { - } 12 \text { fathers } \\
\text { who had } \\
\text { supported their } \\
\text { wives during } \\
\text { childbirth }\end{array}$ & IDIs & $\begin{array}{l}\text { Husbands } \\
\text { helped to be } \\
\text { present at the } \\
\text { birth. They had } \\
\text { helped to boost } \\
\text { their wife's } \\
\text { confidence and } \\
\text { reduce her } \\
\text { anxieties about } \\
\text { the delivery. }\end{array}$ & $\begin{array}{l}\text { - Despite the } \\
\text { unpleasant } \\
\text { emotions, a } \\
\text { majority of the } \\
\text { husbands felt } \\
\text { that they were } \\
\text { able to support } \\
\text { their wives to } \\
\text { some extent. }\end{array}$ & $\begin{array}{l}\text { - Husbands } \\
\text { in this study } \\
\text { are from an } \\
\text { urban setting, } \\
\text { where } \\
\text { people's } \\
\text { educational } \\
\text { qualifications } \\
\text { and their } \\
\text { access to } \\
\text { maternity } \\
\text { health } \\
\text { services are } \\
\text { high }\end{array}$ & \\
\hline
\end{tabular}


Table 3

Synthesis of qualitative findings on the role of social capital and use of maternal and child health services

\section{Findings}

Across network support patterns, most women indicated that network members were caring/ showed empathy in their interactions with them

Network members visited daily during her pregnancy

Mothers could be relied upon to empathize with their daughter's situation

Most women received advice to use facility-based pregnancy and delivery care

It is socially normative for in-laws, particularly Mother in laws[MIL], mothers and grandmothers to advice women and provides suggestions on how to experience safe pregnancy and delivery

Network members lived in close proximity, and generally had good relationships, with the women. Woman interacted with her husband and in-laws daily because they lived in the same house

When her husband is not there.. .you [MIL] would then talk to any family member available at that time, for that person to look for a motorbike, fuel it and take her to hospital

\section{support}

Network members able to help her access and utilize facility delivery

Some network members tended to first seek the involvement of a traditional birth attendant (TBA) during women's labor and did not make timely arrangements to transport women to a facility

Some women had numerous sources of support, their own mothers, female relatives and friends.

WDA leaders are good in passing different knowledge to mothers and members of the community during community meetings, women's association meetings, antenatal outreach sessions, and coffee ceremony

Promotion of health care services
Synthesized findings

Social supports enabled women to use facility-based ANC and delivery care.

Different kinds of social network supports from conception to the early childhood period direct women's place of childbirth

HEWs, WDA and religious leaders are also participating on community mobilization activities including use of full ANC services, health facility delivery and PNC

Assistance with community fund raising, facilitating ambulance services or traditional ambulances to get women to the health center for delivery, providing training for model family/WDA

Integrating activities between community leaders, including WDA leaders, religious leaders and HEWs, are all considered to be bridges and enhance strong relationship and communication between HEWs, primary health care units and community members

There are some members of the community who cannot go to the hospital for health care services for whatever problem without first going to herbalists

III health is as a result of evil spirits and traditional systems of health care were bestplaced to deal with them

Only opting for a facility delivery if complications arise during the birthing process

In my community, a woman has to stay indoors [for a month to 40 days]

Maternal figures would typically provide TBA services and play a critical role in the decision-making pathway for choice of place of delivery

Islam might forbid women from being seen by other men except their husbands, this was not in line with realities in the health system

Women would avoid seeking health services like delivering in a health facility if no female provider was available

The role of a woman in this community was mainly to give birth and have many children Gender-related power imbalances were also reported
Informational

support

nstrumental
Receiving health information from trusted people enhanced use of maternal health services.
Provision of continuous support

A link between communities and health system

Influence of socio-cultural norms
Socio-cultural factors influenced utilization of maternal health services
Role of significant matriarchal figure

Influence of religious norms

Role of gender stereotypes

\section{Figures}




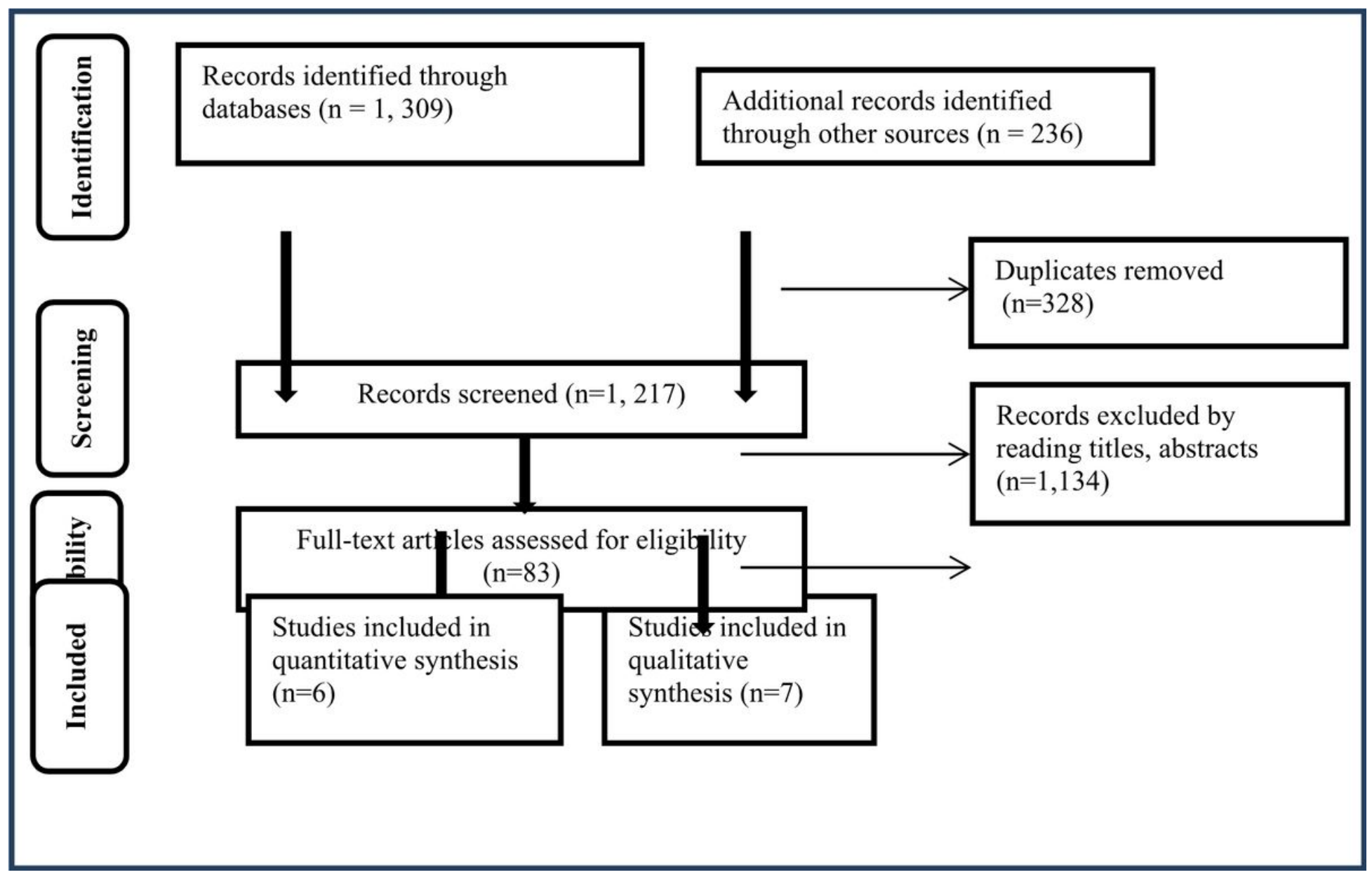

Figure 1

PRISMA flow chart diagram summarizing selection of studies included in the systematic review

\section{Supplementary Files}

This is a list of supplementary files associated with this preprint. Click to download.

- Additionalfile1.docx

- Appendix1and2.pdf 